\title{
Pelaksanaan Asas Hukum Retroaktif Terhadap Penegakan Hukum Pidana Dalam Rangka Efektivitas Pengembalian Keuangan Negara
}

\author{
Subarysah \\ Universitas Pasundan
}

\begin{abstract}
The consequence of within the legality principle in Indonesian legislation is the prohibition of retroactively imposing a criminal legislation or known as non-retroactive, related to the financial losses of the state especially regarding the criminal act of corruption that occurred prior to the issuance of the law, retroactive law in the return of state finances based on the losses incurred to the state caused by a crime, in principle regulated in the PTPK Law because one of the purposes of the enactment of Law no. 31 of 1999 in conjunction with Law no. 20 of 2001 is to restore the state losses. Therefore, the enforcement of criminal law prioritizes the return of state money from corruptor actors, how is the implementation of retroactive legal principle in criminal law enforcement in the framework of effectiveness of state financial return as well as what implications and constraints that arise in the mechanism of implementation of retroactive legal principle in rangaka settlement of state finances.
\end{abstract}

\begin{abstract}
Abstrak. Konsekuensi dari dalam asas legalitas dalam peraturan perundang-undangan di Indonesia adalah larangan memberlakukan surut suatu perundang-undangan pidana atau yang dikenal dengan istilah nonretroaktif, terkait kerugian keuangan negara khususnya mengenai tindak pidana korupsi yang terjadi sebelum keluarnya undang-undang itu, pelaksanaan asas hukum retroaktif dalam pengembalian keuangan negara yang didasarkan kepada kerugian yang terjadi terhadap negara yang disebabkan oleh suatu tindak pidana, secara prinsip diatur dalam UU PTPK karena salah satu tujuan diundangkannya Undang-Undang No. 31 Tahun 1999 jo Undang-Undang No. 20 Tahun 2001 adalah untuk mengembalikan kerugian negara. Oleh karena itu, penegakan hukum pidananya lebih mengutamakan pengembalian kerugian uang negara dari para pelaku tindak pidana korupsi, bagaimanakah pelaksanaan asas hukum retroaktif dalam penegakan hukum pidana dalam rangka efektivitas pengembalian keuangan negara serta Implikasi dan kendala apa yang muncul dalam mekanisme pelaksanaan asas hukum retroaktif dalam rangaka penyelesaian keuangan negara.
\end{abstract}

\section{A. LATAR BELAKANG}

Pancasila merupakan sistem nilai sekaligus penentu arah kebijakan dan program pembangunan sistem hukum nasional.Sejalandengan karakter hukum masyarakat Indonesia yang tercermin dari lima sila dari Pancasila, kita tidak perlu ragukan atau pertanyakan lagi, diperkuat berdasarkan agama dan keyakinan masyarakat yang telah tumbuh dan berkembang selama berabad-abad lamanya di bumi nusantara. Penanaman karakter hukum Pancasila sejak tingkat pendidikan dasar sampai perguruan tinggi bukan hal yang ganjil dan dipaksakan, melainkan merupakan prakondisi untuk dapat menciptakan lulusan pendidikan yang memahami benar hak dan kewajibannya sebagai generasi bangsa Indonesia yang dijamin dan dilindungi UUD 1945 .

Asas hukum merupakan landasan yang paling luas bagi lahirnya suatu suatu peraturan hukum. Satjipto Rahardjo menyebutkan asas hukum sebagai "jantungnya" peraturan hukum atau ratio legis dari peraturan hukum. Asas hukum tidak akan habis kekuatannya dengan melahirkan suatu peraturan hukum, kekuatannya akan tetap ada bahkan hingga ia melahirkan suatu peraturanperaturan selanjutnya. Dengan demikian, asas hukum adalah dasar normatif pembentukan hukum, tanpa asas hukum, hukum positif tidak memiliki makna apa-apa, dan 
kehilangan watak normatifnya, yang pada gilirannya asas hukum membutuhkan bentuk yuridis untuk menjadi aturan hukum positif. Oleh karena itu harus diakui bahwa asasasas hukum mengambil tempat sentral dalam hukum positif. Salah satu asas hukum yang hingga saat ini masih berlaku dan sangat terkenal adalah asas legalitas, dengan tiga pengertian yang terkandung di dalamnya, yaitu :

1. tidak ada perbuatan yang dilarang dan diancam dengan pidana dalam hal ini terlebih dahulu belum dinyatakan dalam suatu aturan perundangundangan;

2. untuk menentukan adanya perbuatan pidana tidak boleh digunakan analogi; dan

3. aturan-aturan hukum pidana tidak berlaku surut.

Meskipun demikian, perkembangan ilmu pengetahuan dan teknologi tampaknya juga berdampak terhadap penerapan asas-asas hukum di Indonesia. Hal ini terlihat dari konfigurasi perdebatan diantara pakar hukum tentang penerapan asas retroaktif dalam sistem hukum Indonesia.

Asas non-retroaktif dalam ilmu hukum pidana secara eksplisit tersirat dalam ketentuan Kitab UndangUndang Hukum Pidana (KUHP), dirumuskan dalam Pasal 1 ayat (1):

" Tiada suatu perbuatan yang dapat dipidana kecuali atas kekuatan aturan pidana dalam perundangundangan yang telah ada, sebelum perbuatan dilakukan".

Bertitik tolak dari uraian mengenai hukum positif dan rancangan undang-undang hukum pidana, dua hal yang sangat penting untuk diketahui masyarakat luas, yaitu pertama, uraian di atas mempertegas kembali bahwa ketentuan mengenai asas non-retroaktif hanya secara tegas diatur dan diberlakukan dalam lingkup hukum pidana materiil bukan dalam lingkup hukum pidana formil (hukum acara pidana) apalagi dalam bidang hukum administrasi yang memang tidak memiliki dasar aturan mengenai hal tersebut baik dalam teori maupun dalam doktrin hukum administrasi, bila melihat ketentuan mengenai asas non-retroaktif, lingkup asas ini hanya dalam konteks apakah suatu perbuatan itu dapat dipidana atau tidak ketika perbuatan itu dilakukan oleh suatu dasar aturan ketentuan pidana yang telah berlaku ketika itu.

$$
\text { Pada }
$$

hakekatnya, pengembalian kerugian keuangan negara akibat tindak pidana sangat penting eksistensinya. Apabila dijabarkan lebih sistematis maka ada beberapa argumentasi sebagai justifikasi teoritis, dan praktis, mengapa pengembalian aset tindak pidana korupsi tersebut penting eksistensinya, dengan harapan pengembalian keuangan negara akan lebih efektif, dan menurut peraturan perundang-undang yang berlaku, sarana yang dapat dilakukan yaitu melalui sarana Penal dan sarana Nonpenal.

Kerugian negara merupakan suatu kerugian yang terjadi karena sebab perbuatan (melawan hukum), kerugian keuangan negara dapat terjadi pada 2 (dua) tahap, yaitu pada tahap Dana yang akan masuk pada Kas Negara dan pada tahap dana akan keluar dari Kas Negara.

Adapun unsur-unsur yang berkenaan dengan pengertian kerugian keuangan negara menurut UndangUndang Pemberantasan Tindak Pidana Korupsi (selanjutnya disingkat UU PTPK) terdapat pada Pasal 2 dan Pasal 3 UU PTPK, lebih lanjut Pasal 4 UU 
PTPK menegaskan bahwa
pengembalian keuangan negara atau perekonomian negara oleh pelaku tindak pidana korupsi tidak menghapuskan dapat dipidananya si pelaku, sekaligus juga merupakan jawaban atas pendapat yang berkembang dalam masyarakat bahwa apabila pelaku tindak pidana sudah mengembalikan uang, maka kerugian negara sudah tidak ada dan perbuatannya tidak bersifat melawan hukum. Sehingga disini faktor pengembalian keuangan negara hanya dijadikan salah satu faktor yang meringankan pidana.

Berkaitan dengan asas hukum retroaktif dikaitkan dengan pengembalian keuangan negara, biasanya tindak pidana yang berkaitan dengan keuangan negara dilakukasetelah tindak pidana tersebut dilakukan, maka apabila terhadap suatu tindak pidana korupsi yang dilakukan sebelum perundang-udangan yang mengatur tindak pidana korupsi serta pengembalian keuangan negara ada, maka jika diberlakukan pengembalian keuangan negara yang merugikan negara oleh pelaku tindak pidana, hal ini sangat bertentangan dengan asas hukum retroaktif, sehingga diperlukan beberapa inisiatif dan terobosan hukum guna menyelesaikan permasalahan tersebut.

Bagaimanakah pelaksanaan asas hukum retroaktif dalam penegakan hukum pidana dalam rangka efektivitas pengembalian keuangan negara serta Implikasi dan kendala apa yang muncul dalam mekanisme pelaksanaan asas hukum retroaktif dalam rangaka penyelesaian keuangan negara?

\section{B. METODE PENELITIAN}

Penelitian ini bersifat deskriftif analitis, yang dalam operasionalnya menggambarkan

peraturan

perundang-undangan tentang

pengembalian keuangan negara dihubungkan dengan asas hukum dan teori-teori hukum, serta bagaimana pelaksanaan atau penerapan hukum berikut implikasi dan kendala dalam mekanisme pelaksanaan asas hukum retroaktif dalam rangka penyelesaian keuangan negara tersebut denganmetode pendekatan yuridisnormatif, sebagai pendekatan yang tidak saja menekankan pada ilmu hukum tetapi juga berusaha menelaah kaidah-kaidah hukum yang berlaku didalam masyarakat.

Studi dokumen dalam penelitian ini dilakukan terhadap data sekunder untuk mendapatkan landasan teoritis berupa pendapat-pendapat atau tulisan-tulisan para ahli dan untuk mendapatkan informasi baik dalam bentuk ketentuan formal maupun data melalui naskah resmi, data yang berhubungan dengan pelaksanaan asas hukum retroaktif terhadap penegakan hukum pidana dalam rangka efektivitas pengembalian keuangan negara Sebagai cara untuk menarik kesimpulan dari hasil penelitian yang sudah terkumpul dalam penelitian ini, akan dipergunakan metode analisis yuridis kualitatif. Analisis yuridis, karena penelitian ini bertitik tolak dari peraturanperaturan yang ada sebagai norma hukum positif. Sedangkan kualitatif, karena seluruh data yang diperoleh kemudian disusun secara sistematis, untuk selanjutnya dianalisa secara kualitatif, guna mencapai kejelasan masalah yang akan dibahas, tanpa menggunakan angka-angka, tabel-tabel maupun rumus statistik.

\section{Hasil Penelitian Dan Analisis Serta Pembahasan Pelaksanaan Asas Hukum}




\section{Retroaktif Terhadap Penegakan Hukum Pidana Dalam Rangka Efektivitas Pengembalian Keuangan Negara}

1. Analisis Asas Hukum Retroaktif Dalam Rangka Efektivitas Pengembalian Keuangan Negara

Kerugian negara yang ditimbulkan dari akibat perbuatan tindak pidana korupsi yang dimaksud adalah adanya kerugian yang ditimbulkan pada keuangan negara atau perekonomian negara. Berdasarkan Pasal 1 ayat (22) Undangundang Nomor 1 Tahun 2004 tentang Perbendaharaan Negara (UU No.1 Tahun 2004), yang dimaksud dengan kerugian negara atau daerah adalah: "Kekurangan uang, surat berharga dan barang yang nyata dan pasti jumlahnya sebagai akibat perbuatan melawan hukum baik sengaja maupun lalai."

Berdasarkan pengertian tersebut di atas, maka dapat dikemukakan unsur-unsur kerugian negara yaitu:

a. Kerugian negara merupakan berkurangnya keuangan negara berupa uang berharga, barang milik negara dari jumlahnya dan/atau nilai yang seharusnya;

b. Kekurangan dalam keuangan negara tersebut harus nyata dan pasti jumlahnya atau dengan perkataan lain kerugian tersebut benar-benar telah terjadi dengan jumlah kerugian yang secarapasti dapat ditentukan besarnya, dengan demikian kerugian negara tersebut hanya merupakan indikasi atau berupa potensi terjadinya kerugian;

c. Kerugian tersebut akibat perbuatan melawan hukum, baik sengaja maupun lalai, unsur melawan hukum harus dapat dibuktikan secara cermat.
Berdasarkan ketentuan Pasal 1 ayat (22) UU No. 1 Tahun 2004 sebagai-mana dikemukakan di atas, maka dapat dilihat bahwa konsep yang dianut yaitu konsep kerugian negara dalam arti delik materiil di mana perbuatan atau tindakan dapat dikatakan merugikan keuangan negara dengan syarat harus adanya kerugian negara yang benar-benar nyata, sedangkan dalam Pasal 2 ayat (1) UU No. 31 Tahun 1999 dijelaskan bahwa kerugian negara dalam konsep delik formil dikatakan dapat merugikan keuangan negara atau per-ekonomian negara.

Undang-undang

pemberantasan tindak pidana korupsi yang baru yaitu UU No. 20 Tahun 2001 dalam Pasal 18 ayat (1) huruf b menyatakan bahwa terhadap pelaku tindak pidana korupsi dapat dijatuhkan pidana tambahan berupa pembayaran uang pengganti yang jumlahnya sebanyak-banyaknya sama dengan harta benda yang diperoleh dari tindak pidana korupsi.

Dalam penanganan perkara korupsi yang dimulai dari penyidikan, penuntutan, upaya hukum yang kemudian apabila sudah mempunyai kekuatan hukum tetap, maka kejaksaan sebagaimana Pasal 270 KUHAP melaksanakan putusan pengadilan yang sudah berkekuatan hukum tetap yakni pidana pokok penjara dan pidana tambahan berupa pembayaran uang denda dan uang pengganti yang mana penagihannya berada pada tanggung jawab pihak kejaksaan sebagai pelaksana putusan (eksekutor) peradilan.

Kondisi tersebut oleh kejaksaan sebagai upaya pengendalian tuntutan pidana kurungan sebagai pengganti kewajiban membayar uang pengganti. Adapun pengendalian tuntutan pidana tambahan tersebut, pedoman 
tuntutan jaksa berdasar Surat Edaran Jaksa Agung RI Nomor: 003/A/AJ/2010 tentang Pedoman Tuntutan Pidana Perkara Tindak Pidana Korupsi, dalam lampiran disebutkan terdakwa dituntut kurungan sebagai pidana pengganti adalah minimal setengah dari tuntutan pidana pokok berupa pidana penjara yang dituntut oleh jaksa penuntut umum.

Proses dalam pelaksanaan putusan uang pengganti yang dilakukan oleh jaksa melalui tahap pengadilan, tahap pelelangan, tahap pembayaran yang pengganti dan gugatan perdata.

Upaya pengembalian kerugian keuangan negara atau perekonomian negara melalui pidana uang pengganti atau tersebut berdasarkan kepada Keputusan Jaksa Agung Nomor: Kep518/J.A/11/2001 tanggal 1 November 2001, Apabila terpidana tidak membayar uang pengganti maka harus ada bukti bahwa terpidana telah menjalani pidana pengganti dan apabila pembayaran tidak dapat sekaligus dilakukan oleh terpidana, maka lebih mengarah kepada penyelesaian non litigasi yang dilakukan dengan negosiasi. Bahwa terpidana dapat membayar dengan cara mengangsur sesuai dengan kesepakatan sampai dengan lunas membayar uang pengganti.

$$
\text { Pada undang-undang }
$$
pemberantasan tindak pidana korupsi yang baru, pada perkara yang diputus, sudah ada pembatasan waktu pembayaran selama satu bulan, apabila tidak membayar uang pengganti maka harta benda dapat disita oleh Jaksa dan harta benda yang disita dapat dilelang untuk menutupi uang pengganti yang jumlahnya sesuai dengan vonis pengadilan yang telah berkekuatan hukum tetap, dan jika terpidana tidak mempunyai harta benda yang cukup untuk membayar uang pengganti, maka dipidana berupa pidana penjara yang dijalani terpidananya yang lamanya tidak melebihi dari pidana pokoknya.

$$
\text { Namun }
$$
permasalahan

muncul,karena Hukum pidana Indonesia pada dasarnya menganut asas legalitas sebagaimana diatur dalam Pasal 1 ayat (1) KUHP yang menyatakan "Tiada suatu perbuatan dapat dipidana kecuali atas kekuatan aturan pidana dalam perundangundangan yang telah ada sebelum perbuatan dilakukan".

Salah satu konsekuensi dari ketentuan tersebut adalah larangan memberlakukan surut suatu perundang-undangan pidana atau yang dikenal dengan istilah non-retroaktif .

Larangan retroaktif, sebenarnya merupakan asas yaitu asas nonretroaktif, asas yang melarang keberlakuan surut dari suatu undangundang. Asas ini sesuai dengan Pasal 2 Algemene Bepalingen van Wetgeving voor Indonesie ("AB"). Dalam hukum pidana, asas ini kemudian dicantumkan lagi dalam Pasal 1 ayat (1) KUHP:

"Tiada suatu perbuatan boleh dihukum, melainkan atas kekuatan ketentuan pidana dalam undangundang, yang ada terdahulu daripada perbuatan itu."

Pemberlakuan hukum pidana secara retroaktif merupakan pengecualian dari asas legalitas atau Principle of legality atas dasar extra ordinary crimes, seperti pelanggaran terhadap hak asasi manusia yang berat. Dengan demikian pemberlakuan hukum pidana secara retroaktif yang dilandasi oleh prinsip keadilan untuk semuanya dalam arti, baik keadilan bagi pelaku tindak pidana maupun keadilan bagi korban tindak pidana merupakan penyeimbang asas legalitas yang semata-mata berpatokan 
pada kepastian hukum dan asas keadilan untuk semuanya. Sehingga pemberlakuan hukum pidana secara retroaktif dengan kondisi-kondisi tertentu, seperti demi kepentingan kolektif baik kepentingan masyarakat, bangsa, maupun negara yang selama ini kurang mendapat perlindungan dari asas legalitas dapat diterima, guna memenuhi tuntutan moral pembalasan masyarakat.

Masalah retroaktif yang ramai dibicarakan adalah, apakah UndangUndang No. 39 Tahun 1999 dan Undang-Undang No. 26 Tahun 2000 dapat juga diberlakukan terhadap kejahatan hak asasi manusia yang terjadi sebelum keluarnya undangundang itu.

Masalah yang perlu mendapat kajian mendalam adalah makna dari retroaktif itu sendiri. Artinya apakah masalah retroaktif hanya berlaku terhadap undang-undang baru yang menciptakan delik baru ataukah juga berlaku terhadap undang-undang baru yang merupakan perubahan dari undang-undang lama, sehingga tidak menciptakan delik baru. Penulis sendiri berpendirian bahwa pemberlakuan retroaktif secara sempit ialah terbatas pada undang-undang baru yang menciptakan delik baru saja dan terbatas pada delik baru yang memenuhi kriteria perbuatan-perbuatan yang membahayakan kelangsungan hidup negara,bangsa dan masyarakat.

Di sini kepentingan yang harus dilindungi adalah kepentingan kolektif baik kepentingan negara, bangsa maupun masyarakat. Dengan demikian, ketentuan Pasal 1 ayat (2) KUHP merupakan aturan peralihan yang bersifat umum.

Dari ketentuan Pasal 4 UU No. 39 Tahun 1999 dan Pasal 28 I ayat (1) UUD 1945, jelas bahwa "Hak untuk tidak dituntut atas dasar hukum yang berlaku surut" merupakan hak absolut dari manusia yang tidak dapat dikurangi atau dibatasi. Pernyataan yang tercantum dalam Pasal 4 UU No. 39 Tahun 1999 ialah hak untuk tidak dituntut atas dasar hukum yang berlaku surut adalah hak asasi manusia yang tidak dapat dikurangi dalam keadaan apapun, tidak berlaku mutlak, karena sesuai dengan penjelasan Pasal 4 UU No.39 Tahun 1999.

Pengecualian terhadap pernyataan bahwa hak untuk tidak dituntut atas dasar hukum yang berlaku surut seperti tercantum dalam penjelasan Pasal 4 UU No. 39 Tahun 1999 sebenarnya tidak sesuai dengan prinsip umum yang tercantum dalam Pasal 1 ayat (1) KUHP yang melarang suatu aturan pidana berlaku secara Retroaktif walaupun didalam penjelasan tersebut dibatasi hanya terhadap pelanggaran berat Hak Asasi Manusia yang digolongkan kedalam kejahatan terhadap kemanusiaan, serta pengecualian/seolah-olah bertentangan dengan ketentuan Pasal 1 ayat (1) KUHP yang melarang suatu aturan pidana berlaku surut, haruslah dipandang sebagai suatu penyimpangan dan masih di dalam tingkatan undang-undang yang sederajat, sehingga disini berlaku asas lex specialist derogat lex generalis artinya undang-undang yang khusus menyampingkan undang-undang yang umum.

Berkaitan dengan sistem
pengembalian keuangan negara,
sebagaimana amanat Pasal $23 \mathrm{C}$ Bab
VIII UUD 1945, keuangan negara
harus diatur dalam undang-undang
terkait dengan pengelolaan hak dan
kewajiban negara. Amanat ini
kemudian dituangkan dalam Undang-
Undang Nomor 17 Tahun 2003


tentang Keuangan negara. Disamping itu dalam diktum menimbang UndangUndang No. 17 Tahun 2003 juga disebutkan latar belakang penyelenggaraan pemerintahan negara untuk mewujudkan tujuan bernegara yang menimbulkan hak dan kewajiban negara yang dapat dinilai dengan uang. Dari sisi subjek, yang dimaksud dengan keuangan negara meliputi seluruh objek sebagaimana tersebut di atas yang dimiliki negara, dan atau dikuasai oleh pemerintah pusat, pemerintah daerah, perusahaan negara/daerah, dan badan lain yang ada kaitannya dengan keuangan negara. Dari sisi proses, keuangan negara mencakup seluruh rangkaian kegiatan yang berkaitan dengan pengelolaan objek sebagaimana tersebut diatas mulai dari perumusan kebijakan dan pengambilan keputusan sampai dengan pertanggungjawaban. Dari sisi tujuan, keuangan negara meliputi seluruh kebijakan, kegiatan dan hubungan hukum yang berkaitan dengan pemilikandan atau penguasaan objek sebagaimana tersebut diatas dalam rangka penyelenggaraan pemerintahan negara.

Berkaitan dengan pembahasan mengenai pelaksanaan asas hukum retroaktif dalam pengembalian keuangan negara yang didasarkan kepada kerugian yang terjadi terhadap negara yang disebabkan oleh suatu tindak pidana, secara prinsip diatur dalam UU PTPK karena salah satu tujuan diundangkannya Undang-Undang No. 31 Tahun 1999 jo Undang-Undang No. 20 Tahun 2001 adalah untuk mengembalikan kerugian negara. Oleh karena itu, penegakan hukum pidananya lebih mengutamakan pengembalian kerugian uang negara dari para pelaku tindak pidana korupsi. Upaya pengembalian kerugian uang negara dari para pelaku korupsi akan berhasil apabila terjadi kerjasama antara aparat penegak hukum (Polisi, Jaksa, KPK) untuk mengungkap tindak pidana korupsi terutama dalam usaha pengembalian kerugian negara. Tanpa adanya kerjasama tersebut akan sulit terjadi suatu pengembalian kerugian keuangan negara/perekonomian negara. Sebab, tidak ada pelaku korupsi yang mau mengembalikan uang negara tetapi dirinya tetap dimasukkan ke dalam penjara. Pelaku korupsi pada dasarnya bersedia mengembalikan uang negara jika perkara pidananya ditiadakan.

Perbandingan proses asas retroaktif dalam pengembalian kerugian negara terkait dalam tindak pidana korupsi di Cina dan Korea Selatan merupakan contoh yang cocok untuk Indonesia. Cina menggunakan strategi penindakan dengan efek jera yang maksimal yaitu dengan hukuman mati, sedangkan Korea Selatan, dengan mengambil pengalaman macetnya roda ekonomi nasional karena setiap gerak peyelenggara negara telah diklaim sebagai penyimpangan/korupsi telah mengubah strategi pemberantasan korupsi kepada strategi pencegahan yaitu dengan membubarkan KPK Korea Selatan dan memperkuat Ombudsman sebagai motor pencegahan dan Kejaksaan secara penuh berwenang dalam penindakan. Cina pada akhirnya telah mengubah strategi ke arah pencegahan dan membatasi strategi penindakan karena terbukti hukuman mati atas pelaku korupsi tidak menimbulkan efek pencegahan dan efek jera yang signifikan. Bahkan dengan strategi pencegahan di Korea Selatan ekonomi nasional telah tumbuh 
pesat dibandingkan ketika dilaksanakan strategi penindakan.

Contoh lain, dan nyata, adalah kasus suap yang melibatkan korporasi Monsanto(Amerika Serikat) beraktivitas di Indonesia yang beraktivitas dalam bidang pestisida, dan oleh korporasi Innospec (Inggris) yang beraktivitas dalam bidang migas. Kedua korporasi tersebut telah melakukan tindak pidana suap terhadap pejabat pemerintah RI, dan di dalam penyidikan Komisi Pemberantasan Korupsi (KPK), KPK telah tidak berhasil menyelesaikan secara tuntas kedua perkara suap tersebut disebabkan UU anti suap di kedua negara tersebut tidak memberikan informasi kepada KPK terkait kedua korporasi tersebut dengan alasan bahwa kedua korporasi tersebut telah memperoleh injunction, sehingga pemerintah khususnya Departemen Kehakiman di kedua negara melalui penetapan pengadilan telah memberikan "pengampunan" dengan menandatangani kesepakatan dengan pemerintah dan membayar denda administrasi sejumlah uang yang ditentukan pengadilan. Kewajiban pihak yang berwenang di kedua negara tersebut adalah melindungi korporasi tersebut dari tuntutan perdata dan pidana dan tidak dibolehkan memberikan keterangan apapun mengenai "track-record" korporasi tersebut kepada pihak lain. Dalam contoh ini, jelas bahwa kebijakan hukum di kedua negara tersebuttidak dapat dipersalahkan, telah bersikap "meringankan" beban moril dan materiel korporasi tersebut dan tetap dijaga reputasinya di kalangan pebisnis internasional. $\mathrm{Hal}$ ini disebabkan dengan pertimbangan bahwa kedua korporasi merupakan wajib bayar pajak yang patuh dan telah memberikan devisa yang signifikan kepada negaranya. Contoh tersebut perlu dikaji di dalam kebijakan hukum Pemerintah Indonesia di masa yang akan datang khususnya di dalam menghadapi dan memasuki era perdagangan global dalam konteks pemberantasan korupsi. Dalam pandangan penulis, kebijakan hukum pemerintah di kedua negara tersebut (AS dan Inggris) dalam penegakan hukum khususnya pemberantasan korupsi, adalah dalam rangka menciptakan iklim usaha yang kompetitif dengan tujuan mencapai peningkatan perekonomian nasional. Pendekatan pragmatis-utilitarian di dalam kebijakan hukum kedua pemerintah asing tersebut jelas membuktikan bahwa tujuan penghukuman (fisik)retributif, bukan tujuan utama dan lebih meningkatkan strategi pencegahan (preventif).

Pengembalian kerugian keuangan negara atau perekonomian negara hanya merupakan salah satu faktor yang meringankan saja. Artinya pengembalian kerugian keuangan negara tidak menghilangkan dipidananya pelaku tindak pidana korupsi. Dalam praktek penegakan hukum, keadaan ini memberi dampak pelaku korupsi lebih cenderung untuk menerima pengenaan pidana daripada mengembalikan kerugian keuangan negara tersebut. Hal ini kemudian juga melahirkan dampak berikutnya seperti efek domino, yaitu tingkat pengembalian kerugian uang negara yang dari tahun ke tahun menjadi relatif kecil. Dampak ini tentu tidak sesuai dengan salah satu tujuan diundangkannya UndangUndang Nomor 31 Tahun 1999 yaitu untuk mengembalikan kerugian keuangan negara.

Pemberlakuan hukum secara 
surut (retroaktif) merupakan penyimpangan dari prinsip utama hukum pidana (legalitas) sebagaimana tercantum dalam Pasal 1 ayat (1) KUHP, namun teradapat pengecualian atas asas retroaktif menurut Prof. Jimly Asshidiqie hanya dapat diberlakukan pada kejahatan terhadap kemanusiaan. Dalam Penjelasan Pasal 104 UU No.39 Tahun 1999 tentang Hak Asasi Manusia, kejahatan terhadap kemanusiaan disebut dengan pelanggaran hak asasi manusia yang berat seperti pembunuhan massal (genocide), pembunuhan sewenangwenang atau di luar putusan pengadilan (arbitrary/extra judicial killing), penyiksaan, penghilangan orang secara paksa, perbudakan, atau diskriminasi yang dilakukan secara sistematis (systematic diserimination). Sedangkan korupsi tidak termasuk di dalamnya.

Dalam konteks penting dan relevan strategi pencegahan dan pengembalian aset hasil korupsi maka ketentuan Pasal 4 UU RI Nomor 31 Tahun 1999 telah bertentangan dengan tujuan pengembalian aset korupsi dan strategi pencegahan karena karena tidak akan ada seorang tersangka pun yang berniat mengembalikan uang negara sambilmenyerahkan dirinya untuk dituntut dan diadili. Konsekuensi dari ketentuan ini telah terjadi buron korupsi yang melarikan diri ke negara lain dengan membawa aset hasil kejahatannya.

Mengenai penyimpangan atau pengecualian dari asas larangan berlaku surut ini, oleh E.Y. Kanter, S.H. dan S.R. Sianturi, S.H. dalam bukunya Asas-Asas Hukum Pidana di Indonesia dan Penerapannya, dikatakan bahwa ketentuan dalam Pasal 1 ayat (1) KUHP tidaklah berlaku mutlak. Pengecualian atau penyimpangan dari ketentuan tersebut dapat dibuat oleh pembuat undang-undang dengan peraturan yang sederajat. KUHP (Wetboek van Starfrecht) disetarakan dengan "undang-undang" sehingga pengecualian atau penyimpangan asas retroaktif bisa dilakukan dengan menerbitkan undang-undang.

Dengan demikian, sepanjang UU PTPK yang saat ini berlaku (UU No. 20 Tahun 2001 tentang Perubahan Atas UU No. 31 Tahun 1999 tentang Pemberantasan Tindak Pidana Korupsi-"UU Pemberantasan Tipikor") tidak mengatur atau memberikan peluang diberlakukannya asas retroaktif, maka pemberlakuan surut hukum untuk tindak pidana korupsi belum dapat dilakukan.

Karenanya, apabila hakim menerapkan asas retroaktif dalam perkara korupsi, dapat dikatakan hakim salah menerapkan hukum, sehingga terhadap ini dapat ditempuh upaya hukum kasasi (Pasal 244 UU No. 8 Tahun 1981 tentang Hukum Acara Pidana-"KUHAP").

Keputusan Hakim demikian sebagaimana disebutkan di atas, selanjutnya akan dilaksanakan oleh Jaksa. Jaksa sebagai pelaksana putusan pengadilan harus melaksanakan isi putusan Hakim tindak pidana korupsi yang telah memiliki kekuatan hukum tetap sepanjang putusan tersebut belum dibatalkan (Pasal 1 angka 6 KUHAP jo. Pasal 30 ayat (1) huruf b UU No.16 Tahun 2004 tentang Kejaksaan Republik Indonesia).

Selain itu dalam kaitannya, asas legalitas dengan UU No.8 Tahun 2010 tentang Pencegahan dan Pemberantasan Tindak Pidana Pencucian Uang adalah terkait dengan dikriminalisasinya pencucian uang menjadi suatu perbuatan yang dilarang 
atau tindak pidana yang dilarang dalam UU No.8 Tahun 2010 khususnya yang menyangkut dengan pemeriksaan di sidang pengadilan terkait dengan pembuktian terbalik yang telah diatur (dilegalkan) dalam Pasal 77 UU No.8 Tahun 2010. Ketentuan pasal ini menentukan, "Untuk kepentingan pemeriksaan di sidang pengadilan, terdakwa wajib membuktikan bahwa harta kekayaannya bukan merupakan hasil tindak pidana". Dengan demikian, berdasarkan asas legalitas pembuktian terbalik telah dianut dalam Pasal 77 UU No.8 Tahun 2010.

Pengecualian terhadap asas legalitas terdapat dalam Pasal 94 dan Pasal 95 UU No.8 Tahun 2010. Ketentuan dalam Pasal 94 menyangkut tugas Pusat Pelaporan dan Analisis Transaksi Keuangan (PPATK) harus tunduk pada UU No.8 Tahun 2010 tetapi kecuali mengenai struktur organisasinya masih tetap berpedoman pada UU No.15 Tahun 2002 jo UU No.25 Tahun 2003. Sedangkan ketentuan dalam Pasal 95 menentukan batasan terhadap kasus-kasus tindak pidana pencucian uang yang dilakukan sebelum berlakunya UU No.8 Tahun 2010, diperiksa dan diputus berdasarkan ketentuan dalam UU No.15 Tahun 2002 jo UU No.25 Tahun 2003.

Berdasarkan analisis dan pembahasan di atas, terjawab bahwa sampai saat ini, pemberlakuan asas retroaktif belum dimungkinkan oleh UU Pemberantasan Tipikor. Sehingga, Hakim tidak seharusnya memberlakukan surut hukum untuk perkara korupsi kecuali ada peraturan (undang-undang) yang memungkinkannya.

2. Implikasi Dan Kendala Apa Yang Muncul Dalam
Penerapan Asas Hukum

Retroaktif Dalam Rangka

Efektivitas Pengembalian

Keuangan Negara

Pengembalian Kerugian Negara sebagaimana sudah diketahui dalam Pasal 2 dan Pasal 3 Undang-Undang Nomor 31 Tahun 1999, bahwa salah satu unsur dari indak Pidana Korupsi adalah dapat merugikan keuangan negara atau perekonomian negara. Menurut Pasal 4 Undang-Undang Nomor 31 Tahun 1999, pengembalian kerugian keuangan negara atau perekonomian negara tidak menghapus pidananya pelaku tindak pidana sebagaimana dimaksud dalam Pasal 2 dan Pasal 3 Undang-Undang Nomor 31 Tahun 1999. Oleh karena itu, bila pelaku Tindak Pidana sebagaimana dimaksud dalam Pasal 2 dan Pasal 3 telah memenuhi unsur/elemen pasal dimaksud, maka pengembalian kerugian keuangan negara atau perekonomian negara tidak menghapuskan pidana terhadap pelaku tindak pidana tersebut.

Dalam penjelasan umum atas UU No. 31 Tahun 1999 disebutkan mengenai keuangan negara adalah seluruh kekayaan negara dalam bentuk apapun yang dipisahkan atau yang tidak dipisahkan, penerapan pidana uang pengganti dan denda merupakan salah satu upaya untuk mengembalikan kerugian keuangan negara. Jika dilihat dari undangundang korupsi yang ada, semua menerapkan pidana uang pengganti, kelemahannya formulasi demikian bahwa dalam undang-undang tersebut tidak secara tegas menentukan kapan uang pengganti itu harus dibayarkan, dan apa sanksinya bila pembayaran tidak dilakukan. Hanya dalam bagian penjelasan undang-undang tersebut disebutkan, apabila pembayaran uang pengganti tidak dapat dipenuhi, 
berlakukan ketentuan-ketentuan tentang pembayaran denda,hal ini-lah yang menjadi kendala dalam proses pengembalian keuangan negara jika dikaitkan dengan asas hukum retroaktif.

Persoalan retroaktif sendiri muncul sebagai konsekuensi diterapkannya asas legalitas. Asas legalitas sendiri dapat dikaji berdasarkan berbagai aspek, seperti aspek historis, aspek sosio kriminologis, aspek pembaharuan hukum dalam kaitannya dengan pandangan secara imperatif dan linier, aspek yang terkait dengan politik kriminal serta kajian dari perspektif weltanschaung kita yaitu Pancasila.

Kajian dari masing-masing aspek ini memberi implikasi yang berbeda mengenai asas legalitas yang mana dalam pandangan ilmu pengetahuan perbedaan itu justru akan memperkaya khasanah ilmu hukum pidana itu sendiri, Larangan pemberlakuan surut suatu peraturan pidana (retroaktif) yang tercantum dalam Pasal 28 I ayat (1) UUD 1945 Amandemen Kedua menimbulkan implikasi peraturan di bawah UUD 1945 tidak dapat mengeyampingkan asas tersebut. Kenyataan yang timbul adalah ada pengecualian terhadap larangan tersebut yang diatur "hanya" dengan undang-undang yang dalam hirarkis perundang-undangan masih berada di bawah UUD 1945. Problematika ini menimbulkan persoalan dalam hukum pidana dan hirarki perundang-undangan.

Selain itu larangan penerapan peraturan pidana secara retroaktif ternyata menimbulkan persoalan yang rumit terutama dalam menghadapi kejahatan jenis baru yang tidak ada bandingannya dalam KUHP atau peraturan pidana khusus lainnya.
Adakah kejahatan yang sedemikian dibiarkan.

\section{KESIMPULAN DAN SARAN}

muncul sebagai konsekuensi diterapkannya asas legalitas. Asas legalitas sendiri dapat dikaji berdasarkan berbagai aspek, seperti aspek historis, aspek sosio kriminologis, aspek pembaharuan hukum dalam kaitannya dengan pandangan secara imperatif dan linier, aspek yang terkait dengan politik kriminal serta kajian dari perspektif weltanschaung kita yaitu Pancasila, kajian dari masing-masing aspek ini memberi implikasi yang berbeda mengenai asas legalitas yang mana dalam pandangan ilmu pengetahuan perbedaan itu justru akan memperkaya khasanah ilmu hukum pidana itu sendiri, Larangan pemberlakuan surut suatu peraturan pidana (retroaktif) yang tercantum dalam Pasal 28 I ayat (1) UUD 1945 Amandemen Kedua menimbulkan implikasi peraturan di bawah UUD 1945 tidak dapat mengeyampingkan asas tersebut.

Kenyataan yang timbul adalah ada pengecualian terhadap larangan tersebut yang diatur "hanya" dengan undang-undang yang dalam hirarkis perundang-undangan masih berada di bawah UUD 1945.

\section{DAFTAR PUSTAKA}

Abubakar Busro, Nilai dan Berbagai Aspeknya Dalam Hukum Suatu Pengantar Studi Filsafat Hukum, Bhratara, Jakarta, 1989.

Andi Hamzah. 2007. Pemberantasan Korupsi Melalui Hukum Pidana Nasional dan Internasional. Jakarta: PT RajaGrafindo Persada.

Evi Hartanti, Tindak Pidana Korupsi, SinarGrafika, Jakarta, 2008. 
E.Y. Kanter dan S.R. Sianturi, Asas-Asas Hukum Pidana di Indonesia dan Penerapannya, Storia Grafika, Jakarta, 2002.

Guse Prayudi. 2010. Tindak Pidana Korupsi Dipandang dalam Berbagai Aspek. Yogyakarta: Pustaka Pena.

Moelyatno, Asas-asas Hukum Pidana, Edisi Revisi, Rineka Cipta, Jakarta, 2008.

Paulus Mujiran, Republik Para Maling, Yogyakarta, Pustaka Pelajar, 2004.

Ronny Hanitijo Soemitro, Metodologi Penelitian Hukum dan Jurimetri, Ghalia Indonesia, Semarang, 1998.

Satjipto Rahardjo, Ilmu Hukum, Citra Aditya Bakti, Bandung, 2000.

Satjipto Rahardjo dan Ronny Hanitijo Soemitro, Pengantar Ilmu Hukum, Cetakan Kedua, Universitas Terbuka, Jakarta, 1986.

Serikat, Nyoman, Putra, Jaya, Beberapa Pemikiran ke Arah Pengembangan Hukum Pidana, PT Citra Aditya, Bandung, 2008.

Syamsudin, M. 2012. Budaya Hukum Hakim Berbasis Hukum Progresif. Jakarta: Kencana.

Tim Redaksi Kamus Besar bahasa Indonesia. 2008. Kamus Besar Bahasa Indonesia. Cetakan Pertama. Edisi IV. Jakarta: PT Gramedia Pustaka Utama.

Yudha Bhakti, Laporan Akhir Tim Kompilasi Bidang Hukum Tentang Asas Rektroaktif, BPHN, Jakarta, 2006.

Ade Paul Lukas. 2010. "Efektivitas Pidana Pembayaran Uang Pengganti Dalam Tindak Pidana Korupsi (Studi Putusan Tindak Pidana Korupsi di
Pengadilan Negeri Purwokerto)". Jurnal Dinamika Hukum, Vol. 10, No. 2 Mei.

Republik Indonesia, Undang Undang Dasar 1945.

$\begin{array}{cr}\text { Republik Indonesia, } & \text { Ketetapan } \\ \text { TAP MPR } & \text { Nomor } \\ \text { XI/MPR/1998 } & \text { tentang } \\ \text { Penyelenggara Negara yang } \\ \text { Bersih dan Bebas Korupsi, } \\ \text { Kolusi, dan Nepotisme. }\end{array}$

Republik Indonesia, Undang-undang Nomor 24 Tahun 1960 tentang Pengusutan,Penuntutan, dan Pemeriksaan Tindak Pidana Korupsi.

Republik Indonesia, Undang-undang Nomor Tahun 1971 tentang Pemberantasan Tindak Pidana Korupsi.

Republik Indonesia, Undang-undang Nomor 28 Tahun 1999 tentang Penyelenggaraan Negara yang Bersih dan Bebas dari Korupsi, Kolusi, dan Nepotisme.

Republik Indonesia, Undangundang Nomor 31 Tahun 1999 tentang Pemberantasan Tindak Pidana Korupsi.

Republik Indonesia, Undang-undang Nomor 20 Tahun 2001 tentang Perubahan Atas Undangundang Nomor 31 Tahun 1999 tentang Pemberantasan Tindak Pidana Korupsi.

Republik Indonesia, Undang-undang Nomor 15 Tahun 2003 tentang Tindak Pidana Pencucian Uang.

Republik Indonesia, Undang-undang Nomor 7 Tahun 2006 tentang Pengesahan United Nations Convention Against Corruption, 2003 (Konvensi Perserikatan Bangsa-Bangsa Anti Korupsi, 2003). 